\title{
Social Entrepreneurship: A Pakistani Perspective
}

\author{
Azra Maqsood and Dr. Javaid Laghari \\ SZABIST \\ Karachi, Pakistan
}

\begin{abstract}
:
Government, businesses, not for profits and local business communities and residents are all impacted by the globalization of the economy and those who live and work in all sectors and regions are the consumers who are also concerned about equity, the environment and sustainability. No one sector creates or can address the problems in isolation from another so new forms of analyzing the problems and responding to them with new sources of capital and cross sectional collaboration are needed.
\end{abstract}

William Drayton, the founder of Ashoka: Innovators for the Public[1] is thought to have coined the term 'social entrepreneur' several decades ago. He is widely credited with creating the world's first organization to promote the profession of social entrepreneurship. Over the last two decades, with the rise of the citizen sector, the popularity of the concept has exponentially increased. In Pakistan alone, Ashoka has since 1996 elected 18 fellows. These fellows work all across Pakistan from Swat to Quetta, to Hyderabad to Khairpur to pure urban populations like Karachi and Lahore in the fields of learning and education; environment; health; human rights; civic participation; economic development. Social Entrepreneurs like Nargis Latif (Gul Baho Trust), Roland De Souza (SHEHRI); Anwar Rashid (Orangi Pilot Project) and Zia Awan (Lawyers for Human Rights and Legal Aid) have already gained international acclaim for their work. These entrepreneurs are unique in the sense that their work has brought about a radical change in the existing social system within a short span of three years. This change is not limited to a neighborhood, but has an impact regionally, nationally and internationally, and all of this has been on a self sustained basis.

A work of this magnitude requires community support, corporate and for profit collaboration and the government's patronage in the form of volunteer support, positive pressure groups, tax relief and multisectoral collaboration. Academia and researchers can fill the gap on research on this 'new' phenomenon of social development, while the government can extend support in publicizing and patronizing various social initiatives. Support in institutional strengthening and capacity building should be offered in collaboration with local and international NGOs to further nurture the work of the social entrepreneurs in Pakistan.

\section{SOCIAL DEVELOPEMNT IN PAKISTAN}

\subsection{Introduction}

According to Shahnaz Wazir Ali[2] the concept of social development has undergone an important change in the last few decades. She observes that the state was to be the main provider of social services to people, namely education, health care, water and sanitation, access to credit and some skills training for employment. Due to the lack of democratic dispensation, advocacy, and human rights groups assertively entered the arena of the civic activity. These groups were of the view that development involves more than just putting children in schools, immunizing them or providing access to water and sanitation; in fact the real issue is about equal rights ---- the right to safety, survival, physical security, freedom of association, speech, movement and thought. In today's society, people view social development as encompassing both these fundamental rights and the actions society needs to take in order to ensure those liberties and rights[3].

The role of the government is changing, from the state as the predominant provider of services to the state as a planner, facilitator and financier. As a result, the state is slowly beginning to recast itself as the player that must ensure that conditions exist to make services efficiently available. Through the fiscal and management policies of the state its regulatory mechanisms, and the incentives it provides to the private sector, the state can create the right conditions for social development to flourish. The fundamental obligation of the state is to ensure basic services for all. The state cannot abdicate its responsibility to provide basic development infrastructure, as it is not possible for the private or the nonprofit sector to provide wide access and ensure equity. Yet the state can provide incentives and opportunities for a number of nonprofit organizations to expand and strengthen their reach. The state should concern itself with the setting and monitoring of standards, ensuring equity, actively promoting participation and empowerment, assessing the impact and outcomes, and providing a policy that acknowledges that intellectual and social assets are not 
the main domains of the government. Society's contribution, both formally and informally, is the main force for generating new ideas and spurring action[4].

The UNDP in 1998 identified the roles and responsibilities of the different groups that mobilize and strengthen the social development, and in turn ensure poverty reduction. These are governments; individuals and household; community organizations and NGOs; private sector producers; and international institutions.

\subsection{Government's Role in Social Development}

To mitigate the causes of social development and poverty, the Government has recently introduced several important governance-related reforms to improve the functioning of State institutions and strengthen their capacity and accountability with an aim to provide greater public access to better quality social sector related, judicial, and other services. Historically, various other poverty targeted policy interventions and programs have also been initiated from time to time in the public sector in Pakistan, which can be categorized into three broad sectors: public works programs for asset creation and employment generation; micro finance programs to promote income opportunities; and social protection programs. [5]

\subsection{Role of Individuals and Household in Social Development}

Dr Attiya Inayatullah [6] in an article in DAWN in 2000 says that Pakistan is among the most giving nations in the world. She quoted the principal finding of the first National Survey on Individual Giving, undertaken in 1998-99 for the Initiative on Indigenous Philanthropy. The survey explored the individual giving of money, goods and time. It also addressed personal factors that may affect individual giving, including gender, residence, income, age and family background.

The single most important determinant of giving appears to come from the family. Across all categories of giving, parental involvement in philanthropic activities markedly increased a given individual's participation. For example, individuals whose parents had given time comprised 71 per cent of volunteers, as compared to the three per cent of volunteers whose parents had not donated time.

Ninety per cent of surveyed donors cited religious faith as a motivation for giving. Of the total share of individual-giving going to organizations, 94 per cent of monetary giving (and 78 per cent of time volunteered) went to religious institutions and causes.

Survey results on voluntary zakat yield further insights into the dimensions and patterns of religious giving. The incidence of voluntary zakat donation by Pakistanis is high: 92 per cent of men surveyed and 96 per cent of the female sample indicated that they had given voluntary zakat in 1998. By contrast, only nine per cent of men and 10 per cent of women reported paying "official zakat" (i.e., zakat extracted automatically from bank accounts or other sources by government). Perhaps most surprising is that seven per cent of this voluntary zakat was given by those with a household income of less than Rs 4,000 per month, and one per cent by those with an income less than Rs 2,000 per month. This suggests a religious commitment to philanthropy that extends beyond what is prescribed.

At January 2002 exchange rates, that individual giving totals $\$ 1.165$ billion. It means that an average Pakistani makes philanthropic contributions of $\$ 8.63$ per year out of personal income/time. With a per capita income of $\$ 460$ per year, that, in turn, means the average Pakistani gave $1.9 \%$ of personal income in 1998, or more than the average 1999 American's cash giving of $1.8 \%$ [7].

\subsection{The NGO Sector}

The non-profit sector has emerged as an important player on the development scene in Pakistan in the last two decades. Its emergence as an active development entity is widely perceived to be a response to the failure of the State in providing effective and efficient basic social services, and in its general suppression, especially during periods of previous military regimes, of organized activity and expression in the country. Today there is much greater general recognition and acceptance than ever before among all stakeholders, including Government, the society at large, and donors as regards the role of the non-profit sector in promoting participatory, equitable and sustainable development. This has resulted in a growing trend towards public private partnerships in development that has, in turn, led to an increase in activities of NGOs and civil society organizations in the 1990s. A recent study conducted by the Social Policy and Development Center (SPDC) however, attempted to systematically estimate the number of nonprofit organizations. The study estimates that there are about 45,000 registered and non-registered non-profit institutions in the country that collectively employ 264,000 people and have an operating annual cash expenditure of Rs. 12,959 million. 
NGOs are working throughout Pakistan in a wideranging set of activities, offering a diverse portfolio of opportunities. Some NGOs are purely welfare oriented, and were formed primarily as charity organizations. Many others are involved in poverty reduction which is a loosely defined objective that may include mainly community-based strategies to improve incomegeneration opportunities, skills development, savings and credit type initiatives, social sector development, and other activities falling under the broader objective of reduction in poverty of the target population. NGOs in this category are mainly engaged in direct service delivery as well as facilitating service delivery through linkages with Government line agencies. There are also some NGOs that exclusively work on undertaking policy advocacy in specified areas.

\subsection{The Role of the Private Sector: Corporate Social Responsibility}

Global trends show companies engaging the community in a variety of ways including donating product and services, creating employee volunteer projects, and loaning executives and managers for a number of socially beneficial reasons. Corporate social responsibility ca be defined as operating a business in a manner that needs or exceeds ethical, legal, commercial and public expectations [8]. It is a comprehensive set of policies, practices and programs that are integrated throughout business operations and decision making processes that are supported and rewarded by top management. These policies refer to a wide range of actions taken by companies to have an impact with their donated money, time, products, services, influence, management knowledge and other resources in the communities and markets that they serve [9].

Various terms such as voluntary code of conduct, corporate self regulation, voluntary initiatives, corporate social responsibility agenda, co regulation (involving corporations, NGOs and multilateral organizations) [10], sustainable development partnerships, sustainable strategies and good corporate citizenship are used to indicate acceptance of responsibility of business for the social and environmental impacts of its activities specially the multinational corporations. Concepts such as state led regulations have often given way to ideas of corporate self-regulation or co regulation.

The concept of corporate social responsibility is very new in Pakistan and has arrived here mostly through partnerships with international non-profit organizations or through MNCs. The common perception among the private sector is that the state does not have the means to deliver on social development. Both foreign and national corporations do contribute, but their contributions are sporadic and their involvement is not systemized. Despite the fact that the paradigm of corporate social responsibility is in its infancy in Pakistan, there are quite a few practices of corporate social responsibility. MNCs like the IBM Pakistan, ICI, KFC/Cupola, Shell, Procter \& Gamble, and local organizations like the Qasrhi Food Industries and Hamdard Laboratories, and smaller superstores or designer clothing manufacturers have showed patterns of corporate social responsibility.

\subsection{Social Entrepreneurship: A Hybrid Model for Social Development}

The concept social entrepreneurship has evolved within a complex framework of political, economic and social changes occurring at the global, national and local levels.

Within a social welfare state paradigm, many social change initiatives were undertaken by the public and/or non-profit sectors, in the latter case drawing on resources transferred from the public sector and/or philanthropic sources. Non-profits were (and to a great degree still are) viewed as valuable contributors to social change. While demand for social services has not decreased in the last two decades the transfer of funding to these organizations has decreased significantly.

There is now a blurring of traditional sectoral boundaries between the public, private and non-profit sectors and the need for new approaches to social problem-solving that incorporate inter-sectoral collaboration. Noting that deeply entrenched social problems are not being solved through the fragmented, currently predominant, single-sector approach, many have argued that all sectors need to work together exchanging and sharing traditionally accepted roles.

This has led to the establishment of a powerful new system of change through social innovation and social impact. Globally, this phenomenon is known as Social Entrepreneurship, and has existed long before the term was coined.

Social entrepreneurship in Pakistan is not a new phenomenon, yet till 1996 no international or local organization had identified social entrepreneurs in Pakistan. Most of the social entrepreneurs that have been identified are social workers, activists, philanthropists, but have been selected as social entrepreneurs based on criteria identified by Ashoka [11], which is the only international organization that 
has elected over 1200 fellows in 44 countries since 1982.

\section{ASHOKA IN PAKISTAN}

Ashoka's mission is to develop the profession of social entrepreneurship around the world by investing in people. It is a global non-profit organization that searches the world for social entrepreneursextraordinary individuals with unprecedented ideas for change in their communities. Ashoka identifies and invests in these social entrepreneurs when no one else will. It does so through stipends and professional services that allow "Ashoka Fellows" [12] to focus fulltime on their ideas for leading social change in education and youth development, health care, environment, human rights, access to technology and economic development.

Ashoka was founded by Bill Drayton, a former McKinsey \& Co. consultant and assistant administrator at the Environmental Protection Agency. An activist since his days as a New York City elementary school student, Drayton is truly a lifelong social entrepreneur. One of the first leaders to recognize the power of individual innovation in addressing pressing social problems, Drayton piloted Ashoka in India with a budget of less than $\$ 50,000$. Today, Ashoka spends more than $\$ 7$ million a year financing its Fellows around the world [13].

The Ashoka representative office is located in Karachi and handled by Fazal Noor and Sadia Fazli. The job of these two representatives is to [14]:

- Identify potential social entrepreneurs in Pakistan, through preliminary interviews, and on site visits (to their facilities/ offices)

- Prepare profiles (according to Ashoka standards) of the candidates and their work

- Organize an interview panel, chaired by Susan Davis [15], twice a year in Karachi

- Recommend shortlisted candidates to the International Ashoka Board US

- Call an annual meeting of Ashoka fellows in Pakistan

- Allocate and disburse monthly stipends [16], and maintain the accounting policies/procedures

- Mobilize funding opportunities for Ashoka fellows

- Arrange capacity building and training workshops and conferences

The first Ashoka fellows in Pakistan were selected in 1996 and to date there are 18 fellows working in various field. Some of these fellows, with their year of election and their organizations are: Nargis Latif (1997, Gulbaho Trust), Roshane Zafar (1997, Kashf Foundation, Lahore), Reaz Ahmed (1997, Faran Education Society), Abdul Hakeem Khoso (1998, Bhittai Welfare Association, Hyderabad), Shaukat Ali Shrar (1998, Shaukat and Associates, Swat), Ghulam Sughra Solangi (1999, Marvi Rural Development Organization, Khairpur), Zia Awan (1999, Lawyers for Human Rights and Legal Aid), Allah Warayo Bozdar (2000, [organization not identified in Ashoka profile]), Nazir Ujjan (2000, Goth Seenghar Foundation, Khairpur), Majeed Mangrio (2000, Makhi Welfare Association, Sanghar), Ajmal Kamal (2002, City Press), Roland de Souza (2002, SHEHRI) and Gulbaz Afaqi (2002, Soon Valley Development Project, Khushan).

As with all change makers, social entrepreneurs face challenges and hurdles in carrying their work forward. Perhaps the most critical hindrance to social development is the rapidly increasing population. It has generally increased the scale of problems and their impacts; the inability to control the rate of population growth is multiplying challenge given the limited resources available to meet the challenge. This has created a "crisis" situation and mentality. The government and people are forced to address the immediate problems rather than improve the system.

Social entrepreneurs working directly with farmers and sharecroppers cited instances where the big landowners and their ties with politicians, bureaucrats and top military people posted on strategic positions in various government agencies hamper all reform activities [17].

There is a lack of vision and no collective agreement on values. Consequently, there is limited or no participation for common good. In reaction to private profit motivated regime, the conservative mindset $\dot{\mathbf{s}}$ becoming common and due to lack of alternative this reactionary psyche has become a norm that reinforces private over public benefit. It is a situation of everyone for himself with little or no care and respect for the weak. The pace of institutional transformation from feudal to modern society is characterized by restricted access to information, limited education and awareness about "life" skills, and lack of transparency and mutual accountability. Traditional bindings and mutual trust is disappearing due to a rapid and profit motivated change process. This change process is characterized by material gains, consumerism and apathy towards public good. The middleman is an integral part of this process, and his interest directs the change process. 
The global media propagates a one sided notion of development and enforces a globalization project that is inappropriate for us. The one sided debate on social and political issues create tensions and promote intolerance.

Support networks are inactive and dormant, and in times of need, inaccessible. Members of such networks are unaware of how to use these networks and generally are unable to relate the benefit to contribution.

Social entrepreneurs lack the capacity and time for fund raising and resource mobilization. They generally prefer to spend time in resolving the problems through meager resources rather than mobilize additional resources, even volunteer help.

\section{CONCLUSIONS AND RECOMMENDATIONS}

- Strategic alliances between 'not for profit' (NFPs) and for profit (FPs) organizations are emerging as a valuable tool for building stronger, healthy and vital communities. A consensus is emerging that no organization can survive on its own in today's interconnected world. The magnitude and complexity of the problems crying out for solutions mandates that all sectors (including government at all levels) must join forces to meet the challenges. Neither NFPs nor FPs will survive and thrive if their visions and activities remain within the walls of their own organizations. The key to achieving shared visions, goals and mutual benefits through collaborative efforts is to understand the nature of such collaborations, the potential pitfalls and the strategies that work in bringing different organizations together.

- In Pakistan, support from the FPs is already available in the form of corporate social responsibility; social entrepreneurs can approach them for cooperation in terms of volunteer time, monetary resources, research publications or welfare documentaries/campaigns (for example, Shell Pakistan has currently undertaken a "Traffic and Road Safety Awareness' campaign in Karachi).

- Social entrepreneurs can lobby support from thee communities in their regions to carry out their work. Nargis Latif, from Gul Baho, mobilizes the Ismaili and the Bohiri communities in Karachi, who assist in setting up the 'Safai Mein Kamai' stalls around their Jamatkhanas.

- Social entrepreneurs have agreed that there is no official or professional documentation of their work; the only official documentation is the work profiles developed by Ashoka (and it has not been updated to include the work of social entrepreneurs who have been elected since 1999). This documentation is important to create awareness of their work. SZABIST students have volunteered to document the work of these social entrepreneurs, and for the purpose of investor interest, develop business plans for their activities.

- Except for a few well established social entrepreneurships, like the Orangi Pilot Project, Gul Baho and the SHEHRI Foundation, there is neither an awareness nor recognition of the other social entrepreneurships. Academic conferences, press conferences, seminars and workshops can be organized and publicized, either through the academic institutions or other FPs that can help in increasing general awareness of the good work that these civil society groups.

- Capacity building and institutional strengthening workshops have to be organized to assist these social entrepreneurs realize their full potential. They currently work without any formal (rather basic) training in accounting, management, negotiation skills, basic computer skills (where computer facilities are available) or marketing. This can also help them in countering the more 'polished' and bureaucratic hurdles that are created by government officials in their areas of work.

- Social entrepreneurs are always short of volunteers; academic institutions can provide students during summer programs, as interns for volunteer work. These students can also help develop fund raising events and activities for social entrepreneurs.

- Perhaps the most difficult, yet the most critical, is for social entrepreneurs to create a pressure group that has a panel of experts from the academia, industry, communities, NGOs, and technocrats, that can take the work of the social entrepreneurs to the higher offices and make the government realize that 
the social entrepreneur is a new yet an important contributor to the social development for a poverty infected Pakistan. Social entrepreneurs do not ask for continued government and international donor funding, like the NGOs, but support from the government in reducing the red tapism and providing access to public information regarding registration laws, taxation procedures, etc that ca facilitate their work.

The society should value social entrepreneurs because they produce benefits that go well beyond the provision of goods and services. These benefits include contributions to the general welfare, to our sense of community, and to the building of a greater civil society, thus reducing poverty. Therefore, the pursuit of desirable social purposes can no more be taken for granted in the case of nonprofit organizations than it can for any other type of organization. Rather, as a society, we must put in place mechanisms and protections to ensure that in reaping the positive benefits that the society has to offer to the development of organizations that have committed themselves to a greater social change and social value contribution in Pakistan.

\section{REFERCENCES}

[1] www.ashoka.org

[2] Shahnaz Wazir Ali is a leading figure in the field of development and politics in Pakistan. An eminent educationist, women's rights activist, political figure, and former government advisor, she is currently the first Executive Director of the Pakistan Center for Philanthropy.

[3] Social Development in Pakistan (2001) Views of Leading Social Sector Personality [Interview with Shahnaz Wazir Ali]
[4] Ibid

[5] Poverty in Pakistan: Issues, Causes and Institutional Responses (2002).

All material and data related to this section of the chapter has been directly downloaded from http://www.adb.org/documents/reports/poverty pak/default.asp

[6] Dr Inayatullah was Minister for Women Development, Social Welfare, Special Education and Population Welfare. This article is drawn from the report on the National Survey of Individual Giving published in Philanthropy in Pakistan. (Aga Khan Development Network, Aug 2000).

[7] www.onphilanthropy.com/op2002-01-25a.html

[8] http://www.bsr.org

[9] Ibid.

[10] http://www.unrisd.org

[11] www.ashoka.org

[12] Ashoka Fellows are selected at least once a year in various countries where Ashoka has its representatives. In Pakistan, the nomination interviews are held twice a year, once in January and the next in June through the Ashoka representatives in Karachi.

[13] The first Ashoka fellows were elected in India in 1982.

[14] Interview with Fazal Noor and Sadia Fazli, Ashoka Representatives in Pakistan

[15] Susan Davis is a member of the International Board Selection Committee, Ashoka: Innovators for the Public

[16] Ashoka fellows are given a monthly stipend of around $\$ 200$ to carry out their work

[17] Reported from the Ashoka Fellows Brainstorming Session held in Karachi in January 2003. 